\begin{tabular}{|c|c|}
\hline Title & A novel sponge derived protein thrombocorticin is a new agonist for thrombopoietin receptor \\
\hline Author(s) & Watari, Hiromi; Nakajima, Hiroya; A tsuumi, W ataru; Nakamura, Takanori; Nanya, Takeshi; Ise, Y uji; Sakai, Ryuichi \\
\hline Citation & $\begin{array}{l}\text { Comparative biochemistry and physiology Part C : Toxicology \& pharmacology, 221, 82-88 } \\
\text { https://doi.org/10.1016/.cbpc.2019.04.003 }\end{array}$ \\
\hline Issue Date & $2019-07$ \\
\hline Doc URL & http:/hdl.handle.net/2115/78805 \\
\hline Rights & $\begin{array}{l}\text { ( 2019. This manuscript version is made available under the CC-BY -NC-ND } 4.0 \text { license } \\
\text { https://reativecommons.org/icenses/by-nc-nd/4.0/ }\end{array}$ \\
\hline Rights(URL) & https://reativecommons.org/icenses/by-nc-nd/4.0/ \\
\hline Type & article (author version) \\
\hline File Information & Watari et al Comp. Biochem Revised(Clean).pdf \\
\hline
\end{tabular}

Instructions for use 


\section{A novel sponge-derived protein thrombocorticin is a new agonist for thrombopoietin receptor}

Hiromi Watari ${ }^{a}$, Hiroya Nakajima ${ }^{a}$, Wataru Atsuumi ${ }^{a}$, Takanori Nakamura ${ }^{b}$, Takeshi Nanya $^{b}$, Yuji Ise ${ }^{c}$, and Ryuichi Sakai ${ }^{a}$

${ }^{a}$ Hokkaido University, Graduate School and Faculty of Fisheries Sciences, 3-1-1 Minato-cho, Hakodate, 041-8611, Japan

${ }^{b}$ Biological Research Laboratories, Nissan Chemical Corporation, Shiraoka-shi, Saitama 349-0294, Japan

${ }^{c}$ Centre for Marine \& Coastal Studies, Universiti Sains Malaysia, 11800 USM, Penang, Malaysia 


\begin{tabular}{ll} 
ARTICLE INFO & ABSTRACT \\
\hline Article history: & We screened 868 marine extracts in search of hematopoietic molecules \\
Received & resulted in findings of several extracts that proliferated Ba/F3-HuMpl cells \\
Received in revised form & but not the cells expressed with other hematopoietic cytokine receptors, \\
Accepted & EPO and G-CSF. Separation of the most potent extract of a Micronesian \\
Available online & sponge Corticium sp., guided by the cell proliferation assay using \\
\hline & Ba/F3-HuMpl cells resulted in an isolation of thrombocorticin (ThC), a \\
Keywords: & novel 14 kDa protein as an active principal. ThC displayed \\
Keyword_1 hematopoietic & concentration-dependent proliferation of Ba/F3-HuMpl cells, and had a \\
cytokine & stronger activity than that of eltrombopag, a small molecule drug used to \\
Keyword_2 thrombopoietin & treat thrombocytopenia. ThC induced phosphorylation of STAT5, \\
Keyword_3 agonist & suggesting that it activates Jak/STAT pathway as in the case of TPO. \\
Keyword_4 marine sponge & These results together indicated that ThC is a specific agonist for c-Mpl, \\
Keyword_5 protein & although the size and shape differs largely from TPO. Here we present \\
isolation, characterization and biological activity of ThC.
\end{tabular}




\section{Introduction}

Mammalian blood is composed largely of red and white blood cells, as well as platelet and lymphoid cells. Although these cells have discrete functions, they all are derived from hematopoietic stem cells (Orkin, 2000). Upon exposure to various hematopoietic cytokines including erythropoietin (EPO), granulocyte colony-stimulating factor (G-CSF), and thrombopoietin (TPO), the cells differentiate and maturated into red, white blood cells and to platelets, respectively. Dysfunction in hematopoiesis causes various disorders including renal anemia, neutropenia, or thrombocytopenia. Therefore, molecules that regulate hematopoietic signal transductions are of great interest as to both biomedical and therapeutic points of view. Several protein-based and small molecular drugs are clinically available to treat hematopoietic disorders. Protein drugs that based recombinant human EPO (Coleman and Brines, 2004) and a modified recombinant human G-CSF (Amadori et al., 2005) are widely used to treat anemia and neutropenia, respectively. Contrary to the above successful examples, use of recombinant human TPO was limited in clinic due to rapid development of antibody that cross-react with endogenous TPO (Li et al., 2001). Besides cytokines, small synthetic peptides with 14-amino acid residues were, surprisingly, found to behave as agonists for EPO receptors (Wrighton et al., 1996). Shortly after, other homologous peptides were also found to serve as TPO receptor agonist (Cwirla et al., 1997). Although the peptides themselves have failed to become clinically useful due to their short half-life in vivo, a TPO receptor agonist 14-mar peptide was eventually developed as an immunoglobulin-conjugated form called "peptibody" that largely improved the half-life issue (Stasi et al., 2008). Romiplostim, the peptibody drug has approved and it is widely used despite its proteinous nature (Molineux, 2011).

Non-peptidyl small molecules that may allow oral administration and favorable pharmacodynamics are advantageous as drug, and thus extensive searches for such compounds with agonist activity for hematopoietic cytokine receptors have been sought (Sakai et al., 2006). Interestingly, a number of small molecules were found to be good agonists for TPO receptor (c-Mpl (Wendling et al., 1994)) whereas only a few compounds were found to activate EPO (Qureshi et al., 1999) or G-CSF (Tian et al., 1998) receptors. Among the small TPO receptor agonists, a compound found from dyestuff library was extensively revolved to develop eltrombopag (Duffy et al., 2001; Duffy and Erickson-Miller, 2007), the first clinically used c-Mpl agonist drug now widely used to treat thrombocytopenia such as idiopathic thrombocytopenic purpura (ITP) (Bussel et al., 2007).

These small molecular drugs were all found from library owned by pharmaceutical companies and are mostly synthetic compounds (Sakai et al., 2006). We thus searched for potential hematopoietic agents from natural sources because natural products often provide unexpected structural features that lead to discovery of novel pharmacophores. For example, a screening of extracts from fungus associated with marine benthic organisms resulted in an isolation of xanthocillins, well known structure but a novel pharmacophore, from marine-derived fungus Basipetospora sp. as c-Mpl agonist (Sakai et al., 2005). This finding prompted us to search further for potential hematopoietic compounds from natural sources. We thus extended the screening study using our marine extract library and found that aqueous extracts of marine sponge showed potent TPO-like activity. Here we describe isolation and physico-chemical characterization of thrombocorticin (ThC), a new protein that can activate thrombopoietin receptor. 


\section{Results}

\subsection{Screening of extracts from marine benthic organisms.}

We tested cell proliferation activity of our marine extract library to search for compounds with hematopoietic activities using $\mathrm{Ba} / \mathrm{F} 3$ murine pro-B lymphoma cell lines. Ba/F3 cells natively express interleukin-3 (IL-3) receptor and proliferate only in the presence of the cytokine. Transfection of gene encoded each human EPO receptor (EPO-R), c-Mpl (TPO-R) or G-CSF-R, results in expression of hEPO-R, hTPO-R and hG-CSF-R on the cell surface, and the cell proliferates in response to IL-3, EPO, TPO or G-CSF, respectively. These cell lines, therefore, are proven to be useful to evaluate molecules that interact with hematopoietic receptors. The cytotoxicity of the extract was first determined by using Ba/F3 cells in the presence of IL-3. Potential hematopoietic activity was evaluated at sub-toxic concentrations of the extract using cells expressed with each hEPO-R, c-Mpl and hG-CSF-R. These cells cannot proliferate and die within two to three days in the absence of appropriate hematopoietic cytokines. When the extract contains compound with the cytokine-like activity, cells are expected to proliferate even in the absence of cytokines. In the present study, we tested aqueous and methanol extracts of marine organisms collected in Republic of Palau and in Chuuk, or Yap State Micronesia, or in Kyusyu, Shikoku and Okinawan coasts in Japan (Table 1).

\begin{tabular}{|c|c|c|c|c|c|}
\hline & \multicolumn{4}{|c|}{ Classifications } & \multirow{2}{*}{ total } \\
\hline & sponge & tunicate & coelenterate & other & \\
\hline Palau & 244 & 47 & 17 & 5 & 313 \\
\hline Chuuk & 233 & 23 & 4 & 6 & 266 \\
\hline Yap & 68 & 0 & 0 & 0 & 68 \\
\hline Japan & 201 & 4 & 1 & 15 & 221 \\
\hline total & 746 & 74 & 22 & 26 & 868 \\
\hline
\end{tabular}

Among the tested, only a small number of extracts exhibited the activity: five Chuuk, two Palau and one from Japan exhibited potent proliferation activity selectively for c-Mpl cells (Table 2). It should be noted, however, that the active five Chuuk specimens are the same sponge identified as Corticium sp. We did not find any extract that proliferate $\mathrm{Ba} / \mathrm{F} 3-\mathrm{HuEPOR}$ or $\mathrm{Ba} / \mathrm{F} 3-H u G C S F R$ cells, whereas each one extract from Chuuk (sponge) and Kyushu (tunicate) proliferated all three Ba/F3 cell lines tested (Table 2). Interestingly extracts from other specimens of Corticium sp. collected in Palau and Yap did not exhibit any proliferation activity.

In summary, we found a total of four extracts of sponge species that selectively proliferated Ba/F3-HuMpl cells. One sponge and one tunicate extracts activated all the Ba/F3 derived cell lines. Two Palauan sponges had activity in both methanol and aqueous extracts, but other active extracts were all aqueous. 


\section{Table 2.}

\section{Number of species activated each of the \\ three types of Ba/F3 cells}

\begin{tabular}{cccc}
\hline & $\begin{array}{c}\text { c-Mpl } \\
(\mathrm{TPO})\end{array}$ & EPO & G-CSF \\
\hline Palau & 2 & 0 & 0 \\
Chuuk & $2(1)$ & $1(1)$ & $1(1)$ \\
Yap & 0 & 0 & 0 \\
Japan & $2(1)$ & $1(1)$ & $1(1)$ \\
\hline
\end{tabular}

Number of sample that proliferate all three cells are in parentheses

\subsection{Isolation of Thrombocorticin ThC}

Because the extracts from Corticium sponges collected in Chuuk were the most potent among the hits, we chose to work on those extracts further. The sponge specimen was extracted with water to give black extract presumably due to melanin in the sponge. The extract was dialyzed against water, to give small- and macromolecular fractions. Because we confirmed that the macromolecular fraction of the sponge stimulated the proliferation of $\mathrm{Ba} / \mathrm{F} 3-\mathrm{HuMpl}$ cells, but not $\mathrm{Ba} / \mathrm{F} 3$ itself, Ba/F3-EPO, nor Ba/F3-G-CSF cells (supplementary data Fig. S1), further separation was guided by Ba/F3-HuMpl assay. Because this result suggested a proteinous nature of the active principal, we next assessed the chromatographic behavior of the active principal using either Sephadex LH-20 or DE52 anion exchange column, then the SDS-PAGE of representing fractions were compared. In both separation modes, active fraction contained bands around $14 \mathrm{kDa}$ (Fig. 1). Note that columns were stained in black in both modes. Rather surprisingly, Sephadex LH-20 successfully separated active proteins.

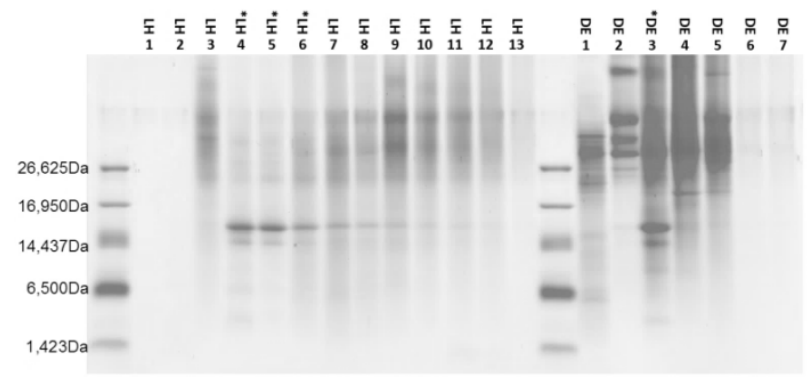

Fig. 1. Protein profiles monitored on a SDS-PAGE for fractions obtained from Sephadex-LH20 (LH1-13) and DE-52 anion exchange column (DE1-7). Fraction with the cell proliferation activity was indicated *. 
A

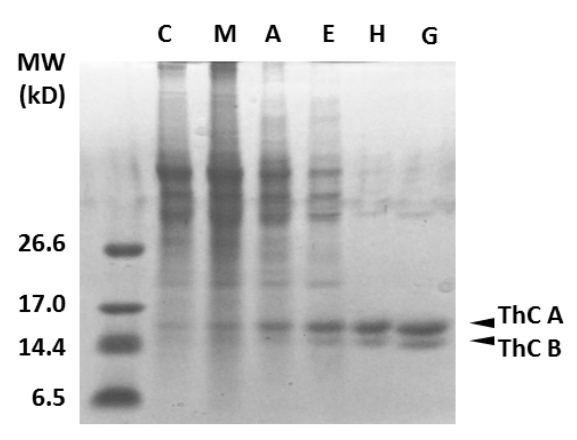

B

$\begin{array}{lll}1 & 2 & 3\end{array}$

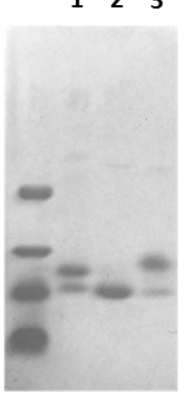

Fig. 2. A. SDS-PAGE for crude extract (C) of the sponge, the macromolecular fraction after dialysis (M), supernatant after acid treatment (A), that after anion exchange chromatography (E), and hydrophobic chromatography (H), and final purification by gel filtration (G). B. SDS-PAGE for purified ThC: with mercaptoethanol and heat treatment (lane 1), with mercaptoethanol but without heat treatment (lane 2), without mercaptoethanol and heat treatment (lane 3).

We further optimized the separation scheme to prevent permanent staining of the columns by melanin, and to be able to handle larger amount of the extract. In this process, we found that the active proteins can be readily separated from other proteins by precipitating by acidic buffer. Thus, the macromolecular fraction from dialysis was suspended in glycine buffer (pH 3.0) to precipitate out other proteinous components. Since the activity was safely recovered exclusively in the supernatant which contained the $14 \mathrm{kDa}$ bands, it was separated on an anion exchange chromatography using DE52 followed by hydrophobic column to afford active fraction. Final separation by a gel filtration column afforded the active protein named thrombocorticin (ThC). ThC could also be purified by using anion exchange column, in that the fraction containing ThC from the Sephadex-LH20 separation was purified by a Mono-Q column to give active protein. SDS-PAGE of ThC exhibited two bands at around $14 \mathrm{kDa}$ in the presence of mercaptoethanol, thus each was denoted as ThC-A and ThC-B, respectively (Fig. 2). Interestingly, however, only ThC-B was observed under non-reduced condition, while ThC-A was observed in the same condition without heating (Fig. 2). These results suggested that reduced ThC can exist as two conformationally different forms.

\subsection{Physico-chemical characterization of ThC}

MALDI-TOFMS for ThC had broad ion clusters at $m / z=13,669[\mathrm{M}+\mathrm{H}]^{+}$as well as those for $[2 \mathrm{M}+\mathrm{H}]^{+},[3 \mathrm{M}+\mathrm{H}]^{+}$, $[4 \mathrm{M}+\mathrm{H}]^{+}$(Fig. 3A). We have observed similar ladder-like ion clusters previously in the MALDI-TOFMS experiment of CchG, a marine sponge-derived galectin (Ueda et al., 2013), indicating these proteins form non-covalent complex in the MALDI condition. An ESI-Orbitrap MS showed ions for $[\mathrm{M}+6 \mathrm{H}]^{6+}$ to $[\mathrm{M}+9 \mathrm{H}]^{9+}$, being the $[\mathrm{M}+8 \mathrm{H}]^{8+}$ as a major ion species. A deconvoluted spectrum showed the presence of major ion with molecular weight of $\mathrm{m} / \mathrm{z}=13,665$ but several minor ions were also observed indicating that the active protein we have obtained contains several minor orthologues (Fig. 3B). 
A

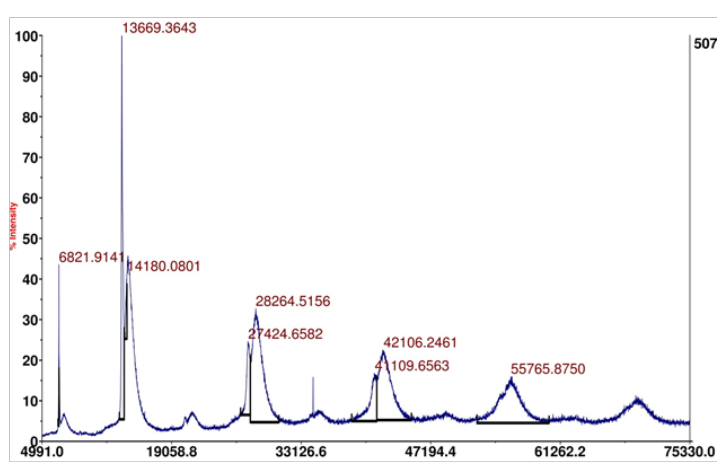

B

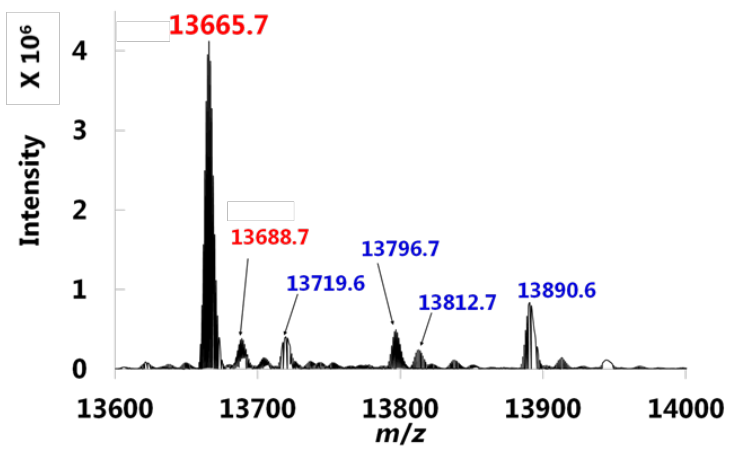

Figure 3. Mass spectral data for the purified protein A. MALDI-TOF and B. A deconvoluted ESI-Orbitrap mass spectrum showing molecular ions $\left([\mathrm{M}+\mathrm{H}]^{+}\right.$and $[\mathrm{M}+\mathrm{Na}]^{+}$) for ThC (red) and putative orthologues (blue).

We therefore used this sample for further experiments, since purification of this sample using HPLC could not remove small amount of the orthologous proteins. Molecular size of ThC was estimated by the gel filtration experiment to be about $25 \mathrm{kDa}$, suggesting that the native ThC forms a dimeric complex (Fig. S2). Treatment of ThC with dithiothreitol (DTT) followed by iodoacetamide (IAA) resulted in formation of alkylated derivative whose molecular ion shifted from $\mathrm{m} / \mathrm{z}$ 13,667 of native protein to 13,773 by 106 Da (Fig. S3), suggesting that one intramolecular disulfide bond presents in the protein.

We next determined $N$-terminal amino acid sequences of ThC. Because SDS-PAGE had a major band ThC-A, and minor band ThC-B, each of the band was cut and subjected to automated Edman degradation to give a tentative sequences: TAXTTGPQQIIPPAA for ThC-A and TAXTTGPXTIIS for ThC-B. These results suggested that ThC-A and B were possibly the same protein, as suggested by the behaviors in SDS-PAGE or orthologous proteins, however, low signal intensity in some amino acids in the sequence analysis hampered rigorous determination. We thus attempted to obtain cDNA using a preserved sample in RNAlater to amplify gene responsible for the production of ThC in the sponge by PCR. Unfortunately, however, construction of cDNA library was not successful presumably due to presence of a large amount of melanin in this species that interfered with mRNA extraction and PCR experiments, and thus improved RNA extraction methods should be applied for future investigations (Islas-Flores et al., 2006). The $N$-terminal amino acid sequences did not have any similarity with previously known proteins, suggesting that ThC is a new compound. 


\subsection{Biological activity of ThC.}

\subsubsection{Proliferation of Ba/F3-HuMpl cells by ThC}

ThC prompted proliferation of Ba/F3-HuMpl cells in a concentration dependent manner. EC $_{50}$ values determined from datasets obtained at pH 7.0, 8.5 and 10 were 22.8, 10.8, and $10.8 \mathrm{nM}$, respectively (Fig. 4). No proliferation activities for Ba/F3-HuEPOR, Ba/F3-HuGCSFR cells or Ba/F3 cells were observed (data not shown). The cell proliferation activity decreased upon heat treatment of the protein, in that the activity was lost gradually by treatment of the protein at $98^{\circ} \mathrm{C}$ for 10, 30, and $60 \mathrm{~min}$ (Table 3). ThC was stable under the acidic condition since acid treatment at $\mathrm{pH} 3.0$ was safely used during the separation. These data indicated that ThC is a small and stable protein. Because ThC behaved similarly to CchG a sponge derived galectin in the MALDI-TOF MS analysis, we tested hemagglutinating activity of the protein. ThC, however, did not aggregate rabbit erythrocyte even at the highest concentration tested $(0.5 \mathrm{mg} / \mathrm{mL})$ indicating that the protein has no lectin-like activity. The stability observed here suggests some structural features of ThC including increases in number of hydrogen bonds, ion pairs, and other factors that contribute to protein stability (Tanaka et al. 2006).

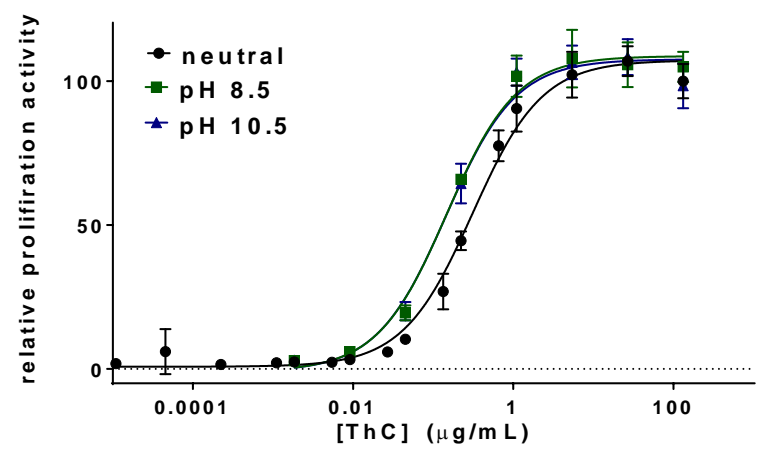

Fig. 4. Concentration-dependent proliferation activity of ThC for Ba/F3-HuMpl cells. Activity was shown relative to $\mathrm{TPO}$ at $10 \mathrm{ng} / \mathrm{mL}$ (100 \%). Each data point is triplicate. Bar \pm SD.

Table 3.

$\mathrm{EC}_{50}$ values for $\mathrm{ThC}$ under various conditions

\begin{tabular}{ccc}
\hline & $\mathbf{E C}_{50}(\mathbf{C I})^{a}$ & $\mathbf{E C}_{50^{b}}$ \\
pH 7.0 & $0.31(0.26 \sim 0.37)$ & 22.8 \\
pH 8.5 & $0.15(0.11 \sim$ & 10.8 \\
& $0.20)$ & \\
pH 10 & $0.15(0.10 \sim$ & 10.8 \\
$98{ }^{\circ} \mathrm{C}, 10 \mathrm{~min}$ & $0.49(0.39 \sim 0.61)$ & 35.9 \\
$98^{\circ} \mathrm{C}, 30 \mathrm{~min}$ & $1.78(1.53 \sim 2.09)$ & 130 \\
$98^{\circ} \mathrm{C}, 60 \mathrm{~min}$ & $7.65(6.58 \sim 8.92)$ & 562 \\
\hline${ }^{a} \mu \mathrm{g} / \mathrm{mL},(\mathrm{CI}, 95 \%$ confident interval $) .{ }^{b} \mathrm{nM}$ \\
\hline
\end{tabular}




\subsubsection{Signal transduction by ThC}

Because selective proliferation of $\mathrm{Ba} / \mathrm{F} 3-\mathrm{HuMpl}$ cells by ThC suggested that the protein act as agonist for TPO-R. Thus the phosphorylation of STAT (Signal Transducers and Activator of Transcription) 5 was assessed by Western blotting analysis, since activation of cMpl results in phosphorylation of Jak (Janus kinase)-2 which in turn phosphorylates STAT5. A dimer of phosphorylated STAT5 finally functions as a transcriptional factor giving rise to cell proliferation. $\mathrm{Ba} / \mathrm{F} 3-\mathrm{HuMpl}$ cell was treated with ThC, and the cell lysates were analyzed by Western blotting with antibody against phosphorylated STAT5 (p-STAT5). ThC induced phosphorylation of STAT5 indicating that it stimulated TPO receptor protein c-Mpl on the cell surface to transduce signals via Jak/STAT signaling pathway.

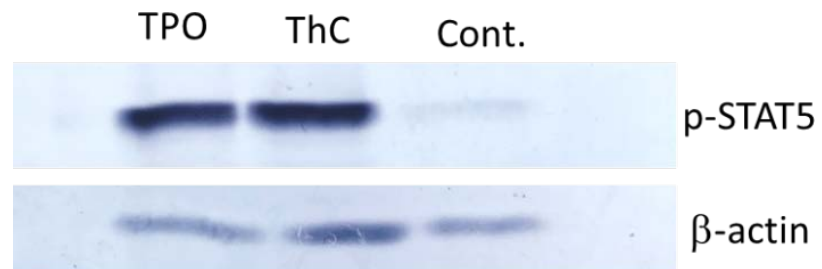

Fig. 6. STAT5 activity by ThC and TPO in Ba/F3-HuMpl cells. Control (Cont.) is untreated cell lysate.

\section{Discussion}

A screening of methanol and aqueous extracts from a total of 868 marine benthic organisms for cell proliferation activity of Ba/F3-HuEPOR, Ba/F3-HuGCSFR, Ba/F3-HuMpl, models of hematopoietic stem cells, resulted in four marine species with selective proliferation activity against $\mathrm{Ba} / \mathrm{F} 3-\mathrm{HuMpl}$, two species with proliferation activity for all the cells tested. No extract with proliferation activity selective for Ba/F3-HuEPOR, Ba/F3-HuGCSFR was found. Two species of Palauan sponges showed activity both in methanol and aqueous extracts. The aqueous extracts of one sponge from Chuuk and one tunicate from the Kyushu proliferated all the $\mathrm{Ba} / \mathrm{F} 3$-derived cells, including $\mathrm{Ba} / \mathrm{F} 3$ cell itself. Active compounds in these extracts can either be non-selective agonist that could stimulate all the hematopoietic receptors or an agonist for IL-3 whose receptor was naturally expressed on the Ba/F3 cells. Identification of active compounds from these species is now under investigation in our group and will be reported elsewhere. Results from the screening study illustrated the difficulty of finding molecules to interact with hematopoietic cytokine receptors; however, this outcome was not surprising to us as this class of receptors have been known to be difficult targets in drug discovery (Schreiber and Walter, 2010). Nevertheless, discovery of a few extracts that can stimulate Ba/F3-HuMpl cells are remarkable as no other natural products, except for xanthocillins, have been known to the best of our knowledge. Furthermore, our finding of novel protein, ThC, that activates TPO receptor is notable as no exogenous protein that possess cytokine-like activity have been known. It should be noted however, small 14-mer peptides were found to activate EPO and TPO receptors (Wrighton et al., 1996). These peptides are known to interact with ligand binding domain of TPO receptor and facilitate dimerization of the receptor to 
form an activated complex. In fact, the dimers of these peptides are far more active than the monomers (Cwirla et al., 1997). These observations led to a development of clinical drug, romiplostim, a hybrid of the small peptide and immunoglobulin Fc fragments (Molineux, 2011).

TPO receptor can also be activated in the other way; eltrombopag, the first commercialized small molecular c-Mpl agonist interacts with a trans-membrane domain of TPO receptor (Drachman and Kaushansky, 1997). Few other small molecular drugs including NIP-022, YM477 and butyzamide are now under clinical trials, but their mechanism of actions are similar to that of eltrombopag (Ikeda and Miyakawa, 2009). In the present work we showed that ThC stimulates the cell proliferation through the Jak/STAT signaling by interacting specifically with cMpl, like other agonists. A comparison of the cell proliferation activity of ThC and other TPO mimetic compounds indicated that the activity of ThC is as potent as other drugs, suggesting that the specific binding of ThC to the receptor facilitates its effective receptor activation. Although detailed mechanism of action is yet to be determined, the high water solubility as well as proteinous nature of ThC preclude its binding to the transmembrane domain. The binding of ThC to the receptor binding domain is likely while no experimental evidences are available at this point. Further investigations including determination of complete amino acid sequence and three dimensional structure of ThC, as well as its mechanism of receptor activation are now in progress in our laboratory.

\section{Table 4}

A comparison of cell proliferation activity for TPO and TPO mimetic compounds

\begin{tabular}{|c|c|c|c|c|}
\hline Compound & type & MW (Da) & $\mathrm{EC}_{50}(\mathrm{nM})$ & Drug status \\
\hline $\begin{array}{l}\text { Romiplostim (Broudy } \\
\text { and Lin, 2004) }\end{array}$ & protein & $50 \mathrm{k}$ & $0.2^{a}$ & marketed \\
\hline rhTPO & protein & $18.6 \mathrm{k}$ & $0.1^{a}$ & - \\
\hline ThC & protein & $14 \mathrm{k}$ & $10^{a}$ & - \\
\hline $\begin{array}{c}\text { AF12505 (Cwirla et } \\
\text { al., 1997) }\end{array}$ & peptide & 1754 & $400^{a}$ & \\
\hline AKR501 (YM477) & & & & \\
\hline $\begin{array}{l}\text { (Fukushima-Shintani } \\
\text { et al., 2009) }\end{array}$ & syn & 649 & $3.3^{a}$ & developing \\
\hline $\begin{array}{c}\text { Butyzamide (Nogami } \\
\text { et al., 2007) }\end{array}$ & syn & 591 & $10^{a}$ & $\begin{array}{c}\text { Approved (Kim, } \\
\text { 2016) }\end{array}$ \\
\hline $\begin{array}{c}\text { NIP-004 (Nakamura et } \\
\text { al., 2006) }\end{array}$ & syn & 455 & $50^{b}$ & - \\
\hline Eltrombopag & & & & \\
\hline $\begin{array}{c}\text { (Erickson - Miller et } \\
\text { al., 2009) }\end{array}$ & syn & 442 & $270^{a}$ & marketed \\
\hline $\begin{array}{c}\text { Xanothocillin (Sakai } \\
\text { et al., 2005) }\end{array}$ & nat & 302 & $13^{b}$ & - \\
\hline
\end{tabular}

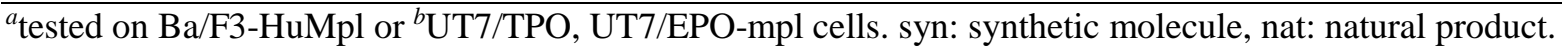




\section{Conclusion}

In conclusion, ThC we found here from the marine sponge was shown to be a new agonist of c-Mpl. The potency of ThC in vitro contest other newly developed drugs and drug candidates and exceeds some of the approved drugs, showing its effective receptor activation. It is not known, however, whether ThC promotes differentiation of blood progenitor cells into megakaryocyte and lead to a formation of platelet, and whether it contributes to platelet activation. Discovery of plural marine extracts with TPO, and IL-3-like activity suggested that diverse of molecules can activate certain group of hematopoietic cytokine receptors. Further studies for mechanism of activation by ThC and other natural products would add deep insight into mode of activation of hematopoietic cytokine receptors.

\section{Experimental}

\subsection{General Procedures}

Tris-tricine SDS-PAGE was performed as described previously (Schagger and von Jagow, 1987).. The protein bands were stained 0.25\% Coomassie Brilliant Blue. BioLogic Duo Flow system (BioRad, Hercules, CA, USA) equipped with QuadTec UV/Vis detector was used for protein separation. An HPLC system equipped with photodiode array detector (Shimazu Kyoto, Japan) was used for separation/purification of protein or peptides. NanoDrop 1000 (Thermo Scientific, Waltham MA, USA). Protein concentration was estimated by assuming $A_{280}=1$ corresponds to $1 \mathrm{mg} / \mathrm{mL}$ protein. For low resolution mass spectral analysis and peptide mass mapping, Matrix Assisted Laser Desorption/Ionization (MALDI) technique was employed using 4700 Proteomics analyzer (Applied Biosystems, Foster City, CA, USA) in a time-of-flight (TOF) linear high/MS mode. $\alpha$-Cyano-4-hydroxycinnamic acid (CHCA) was used as a matrix. High resolution ESI-MS spectrum was measured on LTQ-Orbitrap XL (Thermo Scientific).

\subsection{Biological materials.}

Sponge specimens were collected by SCUBA in Chuuk and Yap state Micronesia, Republic of Palau, Iriomote Okinawa and various locations in Kyushu and Shikoku areas in Japan. Samples were stored in freezer $\left(-20^{\circ} \mathrm{C}\right)$ until use. All collections were made under permission of local governments. The specimen that showed potent activity was identified as Corticium sp. Immediately after the collection of the sponge (CHK151) a portion of specimen was cut in piece (1 mm) and several pieces were stored in RNAlater (Quiagen, Venlo, Holland) for cDNA preparation.

\subsection{Extraction and isolation}

The sponge specimen (CHK129, $53.3 \mathrm{~g}$ ) was lyophilized and the dried sample (11 g) was extracted with water to give an aqueous extract (4.4 g). This material was dialyzed against water using cellulose tube (UC36-32-100, $50 \AA$ pore) to give an inner (1.8 g, CHK129-inner) and an outer fraction (3.0 g). Similarly other sample (CHK151, $10.8 \mathrm{~g}$ ) was extracted and processed to give inner fraction (320 mg, CHK151-inner). To assess chromatographic behavior of bioactive compounds, the later extract $(59.2 \mathrm{mg})$ was first applied on a Sephadex LH20 column $(2.5 \mathrm{x} 114.5 \mathrm{~cm})$ and eluted with water and 
eventually combined into 13 fractions according to protein profiles on SDS-PAGE as well as bioactivity. The same extract (11 mg) was separated on an open column of DE52 (1.5 x $6.5 \mathrm{~cm}$, GE healthcare Japan, Tokyo) using gradient of $\mathrm{NaCl}$ $(0-1 \mathrm{M})$ in $0.1 \mathrm{M}$ Tris-HCl, $\mathrm{pH}$ 8.0, $1 \mathrm{~mL} / \mathrm{min}$. Fractions were combined into seven sub-fractions.

For large scale separation, the inner portion of CHK129 (1.8 g) was suspended in an acidic buffer (200 mM Glycine-HCl buffer, $\mathrm{pH}$ 3.0) to precipitate most of the proteinous component. The supernatant was separated on an anion exchange chromatography using DE52 $(2.5 \times 24 \mathrm{~cm}, 0-0.4 \mathrm{M}$ linear gradient of $\mathrm{NaCl}$ in $20 \mathrm{mM}$ Tris-HCl, pH 8.0, 1 $\mathrm{mL} / \mathrm{min})$. The active fractions were combined, desalted and then lyophilized. The active fraction $(7.5 \mathrm{mg})$ was separated by a gel filtration column TSKgel G2000SW $(7.5 \times 300 \mathrm{~mm}$, TOSOH) eluting with PBS at flow rate of $1 \mathrm{mg} / \mathrm{mL}$ to give fraction ThC (3.1 mg).

\subsection{Cell proliferation assay.}

Murine Ba/F3 cell line and that transfected with human erythropoietin receptor gene, human G-CSF receptor gene, or human c-Mpl gene were established as previously described (Nakamura et al., 2006). Cell lines were maintained in RPMI 1640 medium supplemented with 10\% FBS and rmIL-3, rhEPO, rhTPO, or rhG-CSF. Cells were pre-cultured for 4 days with appropriate cytokine. The cells were harvested by centrifugation (1000 rpm, 3min) and rinsed with PBS, centrifuged, and then were suspended in the medium to $6 \times 10^{4}$ cells/mL. The cell suspension was transferred $(100 \mu \mathrm{L})$ to 96-well microtiter plate and test sample $20 \mu \mathrm{L}$ was added. For positive control rhTPO (Wako Pure Chemical, Japan, 60 ng/mL, 20 $\mu \mathrm{L})$ was added and for negative control medium $(20 \mu \mathrm{L})$ was added. The cells were cultured $\left(37^{\circ} \mathrm{C}, 5 \% \mathrm{CO}_{2}\right)$ for 4 days. Cell counting kit (Dojindo Japan, Kumamoto) was added $(10 \mu \mathrm{L})$ to the wells and absorbance at $450 \mathrm{~nm}$ was measured using microplate reader. Relative cell proliferation was expressed as follows:

$$
\begin{gathered}
\text { Relative cell proliferation activity (\%) = } \\
\left(\text { A450 } \text { sample-A450 }_{\text {Negative }} \text { ) x 100/ (A450 } \text { Positive-A450 }_{\text {Negative }}\right)
\end{gathered}
$$

Assay was performed in triplicate and mean \pm SD was plotted to generate concentration-response curve using Prism software (GlaphPad, San Diego CA).

\subsection{Hemagglutination assay}

To a two-fold serial dilution of ThC in 96-well V-shape bottom microtiter plate, a suspension (4\%, $20 \mu \mathrm{L})$ of rabbit erythrocytes in $20 \mathrm{mM}$ Tris- $\mathrm{HCl}$ was added and the mixture was incubated at $37^{\circ} \mathrm{C}$ for $30 \mathrm{~min}$. Final concentration of the highest ThC was set at $500 \mu \mathrm{g} / \mathrm{mL}$. 


\subsection{Western blotting}

The signal transducing activity of ThC through TPO receptor was assessed by SDS-PAGE and Western blotting. Ba/F3-HuMpl cells were washed 3 times with PBS and suspended in RPMI containing 10\% FBS at a cell density of $1.5 \times 10^{6}$ cells $/ \mathrm{mL}$. The cell suspension was incubated in a $\mathrm{CO}_{2}$ incubator $\left(5 \% \mathrm{CO}_{2}, 37^{\circ} \mathrm{C}\right)$ for $12 \mathrm{~h}$. To $3 \mathrm{~mL}$ of this cell suspension ( $5 \times 10^{6}$ cells), each TPO (final concentration, $100 \mathrm{ng} / \mathrm{mL}$ ), ThC (final concentration, $50 \mu \mathrm{g} / \mathrm{mL}$ ) and control buffer was added. After the mixture was incubated at $37^{\circ} \mathrm{C}$ for $1 \mathrm{~h}$, the cells were centrifuged, washed with PBS. The residual buffer was removed by centrifugation, and then the cell cooled in an ice bath was added the lysis buffer (500 $\mu \mathrm{L}$, CST Japan, Tokyo). The cell lysate was sonicated and then centrifuged to collect the supernatant which was separated by SDS-PAGE (15\%). The separated proteins were electro-blotted onto polyvinylidene difluoride (PVDF) membrane (0.2 mm pore size) at $15 \mathrm{~V}$ for $10 \mathrm{~min}$ and incubated with anti-p-STAT5 (CST Japan) followed by an alkaline phosphatase-labeled second antibody (CST Japan). The antigen-antibody complex formed on the PVDF membrane was visualized with BCIP-NBT Solution Kit for Alkaline Phosphatase Stain (Nacalai Tesque, Kyoto, Japan).

\subsection{Estimation of molecular size}

The above gel filtration column was used to estimate apparent molecular size of ThC. The standard protein mixture containing: triosephosphate isomerase $(26,625)$; myoglobin $(16,950)$; $\alpha$-lactalbmin $(14,437)$; (BioRad) was eluted using a phosphate buffer (50mM, pH 7.0 containing $0.15 \mathrm{M} \mathrm{NaCl}, 1 \mathrm{mg} / \mathrm{mL})$. The void volume of the column $\left(\mathrm{V}_{0}=5 \mathrm{~mL}\right)$, bed volume $\left(\mathrm{V}_{\mathrm{t}}=10 \mathrm{~mL}\right)$ was used to determine Kav. Apparent molecular size was estimated from the calibration curve plotting Kav versus molecular size of the standards.

\subsection{Amino acid sequence determination.}

For the $N$-terminal sequence determination, a sample of ThC (159 $\mu \mathrm{g})$ was separated on a tricine SDS-PAGE, and was blotted on a PVDF membrane, stained by Ponceau-S. The bands of ThC-A and B were each cut out from the membrane and analyzed by automated sequencer, Procise HT Protein Sequencing System (Applied Biosystems).

\section{Acknowledgments}

We are grateful to government of Chuuk and Yap states Micronesia, and Republic of Palau for permission in sample collection. We are grateful to the captain and crew members of Hiroshima University research vessel Toyoshio-Maru. Initial isolation and biological assay were carried out by undergraduate students Shota Nishikawa and Yui Konno in our group. This work was supported by Japanese Grant-in-aid (JSPS) 15H04546 to RS and partly by research grant from Nissan Chemical LTD and JST A-Step.

\section{Appendix A. Supplementary data}

Supplementary data to this article can be found online at 000 


\section{References}

Amadori, S., Suciu, S., Jehn, U., Stasi, R., Thomas, X., Marie, J.-P., Muus, P., Lefrere, F., Berneman, Z., Fillet, G., 2005. Use of glycosylated recombinant human G-CSF (lenograstim) during and/or after induction chemotherapy in patients 61 years of age and older with acute myeloid leukemia: final results of AML-13, a randomized phase-3 study. Blood 106, 27-34.

Broudy, V.C., Lin, N.L., 2004. AMG531 stimulates megakaryopoiesis in vitro by binding to Mpl. Cytokine 25, 52-60.

Bussel, J.B., Cheng, G., Saleh, M.N., Psaila, B., Kovaleva, L., Meddeb, B., Kloczko, J., Hassani, H., Mayer, B., Stone, N.L., 2007. Eltrombopag for the treatment of chronic idiopathic thrombocytopenic purpura. New Engl. J. Med. 357, 2237-2247.

Coleman, T., Brines, M., 2004. Science review: recombinant human erythropoietin in critical illness: a role beyond anemia? Critical Care 8, 337.

Cwirla, S.E., Balasubramanian, P., Duffin, D.J., Wagstrom, C.R., Gates, C.M., Singer, S.C., Davis, A.M., Tansik, R.L., Mattheakis, L.C., Boytos, C.M., 1997. Peptide agonist of the thrombopoietin receptor as potent as the natural cytokine. Science 276, 1696-1699.

Drachman, J.G., Kaushansky, K., 1997. Dissecting the thrombopoietin receptor: functional elements of the Mpl cytoplasmic domain. Proc. Natl. Acad. Sci. U. S. A. 94, 2350-2355.

Duffy, K.J., Darcy, M.G., Delorme, E., Dillon, S.B., Eppley, D.F., Erickson-Miller, C., Giampa, L., Hopson, C.B., Huang, Y., Keenan, R.M., 2001. Hydrazinonaphthalene and azonaphthalene thrombopoietin mimics are nonpeptidyl promoters of megakaryocytopoiesis. J. Med. Chem. 44, 3730-3745.

Duffy, K.J., Erickson-Miller, C.L., 2007. The discovery of eltrombopag, an orally bioavailable TpoR agonist, Target validation in drug discovery. Elsevier, 241-254.

Erickson - Miller, C.L., Delorme, E., Tian, S.S., Hopson, C.B., Landis, A.J., Valoret, E.I., Sellers, T.S., Rosen, J., Miller, S.G., Luengo, J.I., 2009. Preclinical Activity of Eltrombopag (SB - 497115), an Oral, Nonpeptide Thrombopoietin Receptor Agonist. Stem Cells 27, 424-430.

Fukushima - Shintani, M., Suzuki, K.i., Iwatsuki, Y., Abe, M., Sugasawa, K., Hirayama, F., Kawasaki, T., Nakahata, T., 2009. AKR - 501 (YM477) a novel orally - active thrombopoietin receptor agonist. Eur. J. Haematol. 82, 247-254.

Ikeda, Y., Miyakawa, Y., 2009. Development of thrombopoietin receptor agonists for clinical use. J. Thromb. Haemost. 7, 239-244.

Islas-Flores, I., Peraza-Echeverría, L., Canto-Canché, B., Rodríguez-García, C.M., 2006. Extraction of high-quality, melanin-free RNA from Mycosphaerella fijiensis for cDNA preparation. Mol. Biotechnol. 34, 45-50.

Kim, E.S., 2016. Lusutrombopag: First Global Approval. Drugs 76, 155-158.

Li, J., Yang, C., Xia, Y., Bertino, A., Glaspy, J., Roberts, M., Kuter, D.J., 2001. Thrombocytopenia caused by the development of antibodies to thrombopoietin. Blood 98, 3241-3248.

Molineux, G., 2011. The development of romiplostim for patients with immune thrombocytopenia. Ann. N.Y. Acad. Sci. 1222, 55-63.

Nakamura, T., Miyakawa, Y., Miyamura, A., Yamane, A., Suzuki, H., Ito, M., Ohnishi, Y., Ishiwata, N., Ikeda, Y., Tsuruzoe, N., 2006. A novel nonpeptidyl human c-Mpl activator stimulates human megakaryopoiesis and thrombopoiesis. Blood 107, 4300-4307.

Nogami, W., Yoshida, H., Koizumi, K., Yamada, H., Abe, K., Arimura, A., Yamane, N., Takahashi, K., Tanaka, Y., Yamane, A., 2007. A Novel, Small Non-Peptidyl Butyzamide Activates Human Thrombopoietin Receptor and Promotes Megakaryopoiesis. Am Soc Hematology.

Orkin, S.H., 2000. Diversification of haematopoietic stem cells to specific lineages. Nature Reviews Genetics 1, 57.

Qureshi, S.A., Kim, R.M., Konteatis, Z., Biazzo, D.E., Motamedi, H., Rodrigues, R., Boice, J.A., Calaycay, J.R., Bednarek, M.A., Griffin, P., 1999. Mimicry of erythropoietin by a nonpeptide molecule. Proc. Natl. Acad. Sci. U. S. A. $96,12156-12161$. 
Sakai, R., Nakamura, T., Kamiya, H., 2006. Recent advances in thrombopoietic small molecules. Current Bioactive Compounds 2, 395-408.

Sakai, R., Nakamura, T., Nishino, T., Yamamoto, M., Miyamura, A., Miyamoto, H., Ishiwata, N., Komatsu, N., Kamiya, H., Tsuruzoe, N., 2005. Xanthocillins as thrombopoietin mimetic small molecules. Biorg. Med. Chem. 13, 6388-6393.

Schreiber, G., Walter, M.R., 2010. Cytokine-receptor interactions as drug targets. Curr. Opin. Chem. Biol. 14, 511-519.

Schagger, H., von Jagow, G., 1987. Tricine-sodium dodecyl sulfate-polyacrylamide gel electrophoresis for the separation of proteins in the range from 1 to $100 \mathrm{kDa}$. Anal. Biochem. 166, 368-379.

Stasi, R., Evangelista, M.L., Amadori, S., 2008. Novel Thrombopoietic Agents. Drugs 68, 901-912.

Tanaka, T., Sawano, M., Ogasahara, K., Sakaguchi, Y., Bagautdinov, B., Katoh, E., Kuroishi, C., Shinkai, A., Yokoyama, S., Yutani, K., 2006. Hyper - thermostability of CutA1 protein, with a denaturation temperature of nearly $150^{\circ} \mathrm{C}$. FEBS Lett. 580, 4224-4230.

Tian, S.-S., Lamb, P., King, A.G., Miller, S.G., Kessler, L., Luengo, J.I., Averill, L., Johnson, R.K., Gleason, J.G., Pelus, L.M., 1998. A small, nonpeptidyl mimic of granulocyte-colony-stimulating factor. Science 281, 257-259.

Ueda, T., Nakamura, Y., Smith, C.M., Copits, B.A., Inoue, A., Ojima, T., Matsunaga, S., Swanson, G.T., Sakai, R., 2013. Isolation of novel prototype galectins from the marine ball sponge Cinachyrella sp. guided by their modulatory activity on mammalian glutamate-gated ion channels. Glycobiology 23, 412-425.

Wendling, F., Maraskovsky, E., Debili, N., Florindo, C., Teepe, M., Titeux, M., Methia, N., Breton-Gorius, J., Cosman, D., Vainchenker, W., 1994. c-Mpl ligand is a humoral regulator of megakaryocytopoiesis. Nature $369,571$.

Wrighton, N.C., Farrell, F.X., Chang, R., Kashyap, A.K., Barbone, F.P., Mulcahy, L.S., Johnson, D.L., Barrett, R.W., Jolliffe, L.K., Dower, W.J., 1996. Small peptides as potent mimetics of the protein hormone erythropoietin. Science 273, 458-463. 